\title{
Aplikasi Antioksidan Alami Daun Sukun Fermentasi terhadap Produktivitas Itik di KTTI "Unggas Jaya"
}

\author{
Natural Antioxidant Application of Breadfruit Leaf Fermented on Duck \\ Productivity in KTTI "Unggas Jaya"
}

\author{
Elly Tugiyanti, Sigit Mugiyono, Ibnu Harisulistyawan \\ Fakultas Peternakan Universitas Jenderal Soedirman \\ tugiyanti.elly@gmail.com; sigitmugiyono@yahoo.com ; ibnhs@yahoo.com
}

Riwayat Artikel: Dikirim 4 Januari 2019; Diterima 28 Mei 2019; Diterbitkan 31 Mei 2019

\begin{abstract}
Abstrak
Dilatarbelakangi kondisi petani di pedesaan yang pendapatannya rendah dan umumnya petani mempunyai usaha sampingan yaitu beternak. Beternak yang erat kaitannya dengan kehidupan petani adalah beternak itik. Di desa Pegalongan kecamatan Patikraja terdapat Kelompok tani ternak itik (KTTI) yang masih aktif, yaitu KTTI "Unggas Jaya". Permasalahan yang dihadapi oleh kelompok mitra adalah pengadaan bibit, harga pakan, performan itik, harga jual telur dan itik afkir rendah, Solusinya menggunakan daun sukun fermentasi yang berpotensi sebagai bahan pakan itik berkualitas, karena murah, mudah didapat, mengandung vitamin E,C dan A, mineral, antioksidan dan senyawa aktif lain yang bermanfaat bagi kesehatan tubuh ternak itik. Antioksidannya dapat meningkatkan performan, kesehatan, kualitas produk sehingga aman dan berkualitas. Metode untuk memecahkan masalah di kelompok mitra melalui alih tehnologi, praktek (IB, penetasan, fermentasi, pengolahan dan pengemasan produk), evaluasi, pendampingan dan pengkaderan. Target luaran adalah produk, artikel ilmiah popular. Hasil dari demo yang sudah dilakukan adalah : pertumbuhan itik lebih baik daripada sebelumnya, itik lebih sehat-sehat, petani sudah mampu melakukan IB, fertilitas telur hasil IB tinggi yaitu pemeliharaan pejantan lebih dihemat dan peternak dapat menetaskan telur menggunakan mesin tetas.
\end{abstract}

Kata kunci: karkas itik; keamanan pangan; antioksidan; daun sukun, fermentasi

\begin{abstract}
The background is the low income of farmers in rural areas and side business of farmers is raising livestock. Duck raising was closed with farmer lifes. There are active duck farmer groups (KTTI), namely the "Unggas Jaya" in Pegalongan village, Patikraja sub-district. The problems in farmer group are procurement of day old duck, feed prices, duck performance, low selling prices of eggs and culled ducks. Solution of the problem is using fermented of breadfruit leaf which have the potential as quality duck feed ingredients, because they are cheap, easily obtained, contain vitamins $E, C$ and $A$, minerals, antioxidants and other active compounds that are beneficial to ducks health. Antioxidants are safe because the performance and ducks health can be improved. Problem solving method in "Unggas Jaya" farmer groups use by technology transfer, practice (Artificial Incemination, operation of hatching machine, fermentation, product processing and packaging), evaluation, mentoring and cadre of participant. Output targets are products and publication of articles in journal. The results of the demonstrations that have been carried out are: duck growth is better than before. The duck is healthier, farmers are able to do IB, high IB fertility eggs are more conserved and farmers can hatch eggs using hatching machine.
\end{abstract}

Keywords: duck carcasses; food safety; antioxidants; breadfruit leaves, fermentation 


\section{PENDAHULUAN}

Program Pengabdian pada Masyarakat Berbasis Riset ini merupakan aplikasi dari hasil penelitian Riset Institusional sumber dana BLU Unsoed Batch 2 tahun 2015 yang sudah dilakukan bahkan sudah dipublikasikan pada jurnal internasional terindeks scopus. Hasil penelitian menunjukkan bahwa pemberian tepung daun sukun $1 \%$ meningkatkan daya imun itik, meningkatkan kualitas daging, meningkatkan performan itik

Beternak yang erat kaitannya dengan kehidupan petani adalah beternak itik. Salah satu desa yang mempunyai populasi itik cukup tinggi adalah desa Pegalongan yaitu pada tahun 2014 sebanyak 4.240 ekor, karena di Jawa Tengah populasi itik lokal sebanyak 5.582.225 ekor dan di Kabupaten Banyumas populasi itik sebanyak 166.494 ekor (BPS Provinsi Jawa Tengah, 2015). Desa Pegalongan termasuk dalam wilayah Kecamatan Patikraja, Kabupaten Banyumas Jawa Tengah mempunyai luas wilayah 2.264 ha dan $38,2 \%$ merupakan tanah sawah. Jumlah penduduk desa Pegalongan sebanyak 2.262 orang, yang terdiri 1.085 orang pria dan 1.177orang wanita dan 43,2\% penduduk berprofesi sebagai petani. Potensi ini sangat mendukung untuk pengembangan bidang peternakan dan pertanian. Sebagian besar petani yang memelihara itik tergabung dalam kelompok tani ternak itik (KTTI) yang masih aktif, yaitu KT'TI "Unggas Jaya”. Kelompok ini terdiri 14 orang yang diketuai oleh Bapak Sumarto dan dibantu oleh Ibu Erowati sebagai sekretaris. Alasan dibentuknya kelompok adalah sebagai wahana yang tepat untuk saling tukar informasi dan aplikasi teknologi tepat guna untuk perbaikan sistem produksi.

Itik menjadi pilihan usaha sampingan petani yang tergabung dalam KTTI "Unggas Jaya", karena pemeliharaannya mudah, cukup diumbar di sawah, petani tidak mengeluarkan biaya untuk pakan, kemudian produksi telurnya dijual untuk memenuhi kebutuhan hidup hariannya.
Sebagai pangan alternatif kedua setelah ayam, telur dan daging itik mulai disukai oleh masyarakat. Permasalahannya telur dan daging itik mempunyai kandungan lemak dan kolesterol tinggi yang dapat berdampak negatif bagi kesehatan masyarakat. Kandungan lemak dan kolesterol telur itik sebesar 13,77\% dan $884 \mathrm{mg} / 100 \mathrm{~g}$ demikian kandungan lemak dan kolesterol daging itik juga tinggi yaitu $8,2 \%$ dan $1.078 \pm 0.088$ $\mathrm{mg} / \mathrm{g}$ (Poedjiadi dan Supriyanti, 2005; Exler et al., 2013; Huda et al., 2011; Ismoyowati et al., 2012). Solusi yang tepat untuk permaslahan tersebut adalah memanfaatkan antioksidan alami yang banyak ditemui di sekitar dan tidak bersaing dengan kebutuhan manusia, antara lain daun sukun (Artocarpus altilis). Mustafa (1998) menyatakan bahwa daun sukun mengandung fosfor, kalsium, vitamin $\mathrm{C}$, vitamin $\mathrm{B}$. Studi in vitro dan in vivo pada ekstrak daun sukun menunjukkan adanya senyawa flavonoid (Umar et al, 2007) yang dapat membantu memperbaiki kualitas daging seperti warna, bau serta menurunkan kadar kolesterol (Tugiyanti, 2015) dan pemberian tepung daun sukun sebanyak $9 \%$ dalam pakan menghasilkan kadar lemak dan kolesterol yang turun sekaligus meningkatkan daya tahan tubuh (Tugiyanti et al., 2016).

\section{METODE}

Peternak sudah praktek pemeliharaan itik, oleh karena itu metode yang dipilih untuk memecahkan masalah di kelompok mitra adalah melalui alih tehnologi, praktek (IB, penetasan, fermentasi, pengolahan dan pengemasan produk), evaluasi, pendampingan dan pengkaderan.

1. alih tehnologi untuk meningkatkan pengetahuan tentang Pengadaan bibit melalui kawin Inseminasi Buatan (IB), Penetasan telur, Daun sukun dan pemanfaatannya sebagai bahan pakan itik dan Teknik fermentasi. Penyuluhan dilakukan oleh tim dengan pembagian sebagai berikut: 1 . Inseminasi Buatan pada Itik disuluhkan oleh Ir.Sigit Mugiyono,MS.,2. Penetasan Telur 
disuluhkan oleh Ir. Ibnu Hari Sulistyawan,MSc.,3. Pemanfaatan Daun Sukun dan Teknik Fermentasi disuluhkan oleh Dr. Ir. Elly Tugiyanti,MP. Penyuluhan dilakukan selama 3 (tiga) hari dengan bertempat di rumah ketua kelompok.

2. Praktek yang dilakukan selama kegiatan pengabdian kepada masyarakat meliputi Inseminasi Buatan (IB) pada itik, penetasan telur itik menggunakan mesin tetas, Fermentasi daun sukun, Cara pengelolaan dan penyimpanan tepung daun sukun.

3. Evaluasi meliputi pengamatan terhadap fertilitas telur hasil IB, hasil penetasan telur itik ,hasil fermentasi daun sukun, pembuatan tepung daun sukun dan cara ,mencampur ke dalam pakan.

\section{HASIL DAN PEMBAHASAN}

\section{Hasil Pengabdian}

Alih teknologi dilakukan oleh tim dan sebelumnya dilakukan pre test untuk mengetahui sejauhmana peternak mitra mengetahui dari program yang akan kita lakukan. Materi test adalah tentang budidaya ternak itik, pakan itik, Inseminasi Buatan pada itik, penetasan telur menggunakan mesin, dan pemanfaatan tanaman sebagai sumber kesehatan ternak serta cara penggunaannya. Adapun hasil pre dan post test dapat dilihat pada Tabel 1.

Tabel 1.

Hasil Pre Test dan Post Test

\begin{tabular}{|c|l|c|c|}
\hline No & \multicolumn{1}{|c|}{ Materi Penyuluhan } & $\begin{array}{c}\text { Rataan Nilai Pre } \\
\text { Test }\end{array}$ & $\begin{array}{c}\text { Rataan Nilai Post } \\
\text { Test }\end{array}$ \\
\hline 1 & Inseminasi Buatan pada Itik & 67,8 & 72,50 \\
\hline 2 & Penetasan Telur & 60,40 & 70,25 \\
\hline 3 & $\begin{array}{l}\text { Pemanfaatan Daun Sukun Dan } \\
\text { Teknik Fermentasi }\end{array}$ & 60,25 & 70,75 \\
\hline & \multicolumn{1}{|c|}{ Rataan } & 62,82 & 71,17 \\
\hline
\end{tabular}

Setelah alih teknologi selesai maka dilanjutkan dengan kegiatan praktek yang lokasi dari KT'TI “ Unggas Jaya” seperti terlihat pada Gambar 1. dilakukan selama beberapa kali. Adapun

Gambar 1.

Lokasi Kelompok Tani Ternak Itik dan saat pelaksanaan penyuluhan

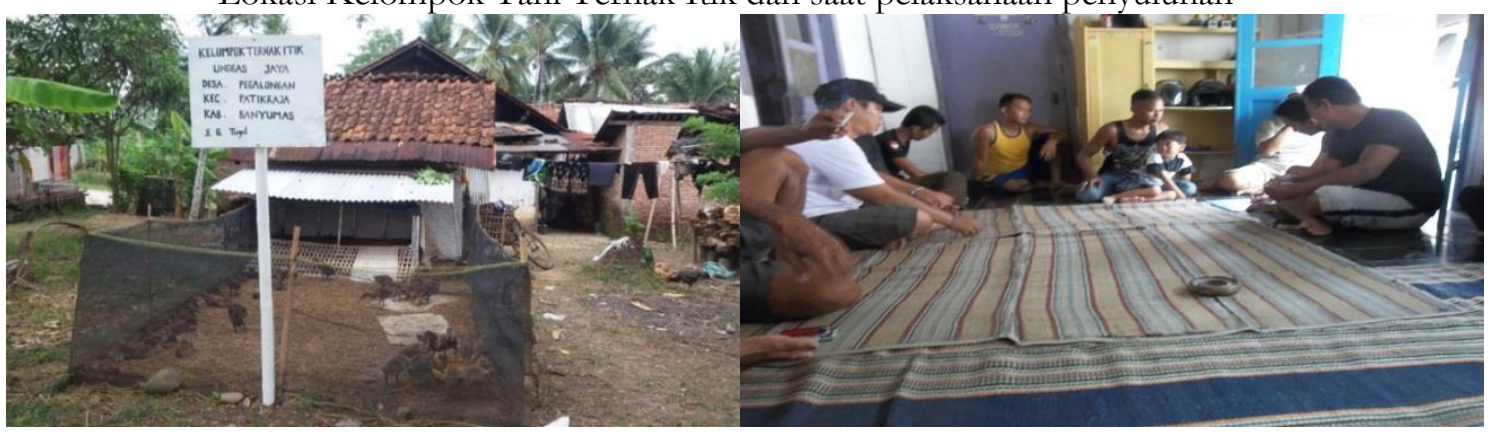


Gambar 2.

Praktek Membuat dan mengoperasikan Mesin Tetas
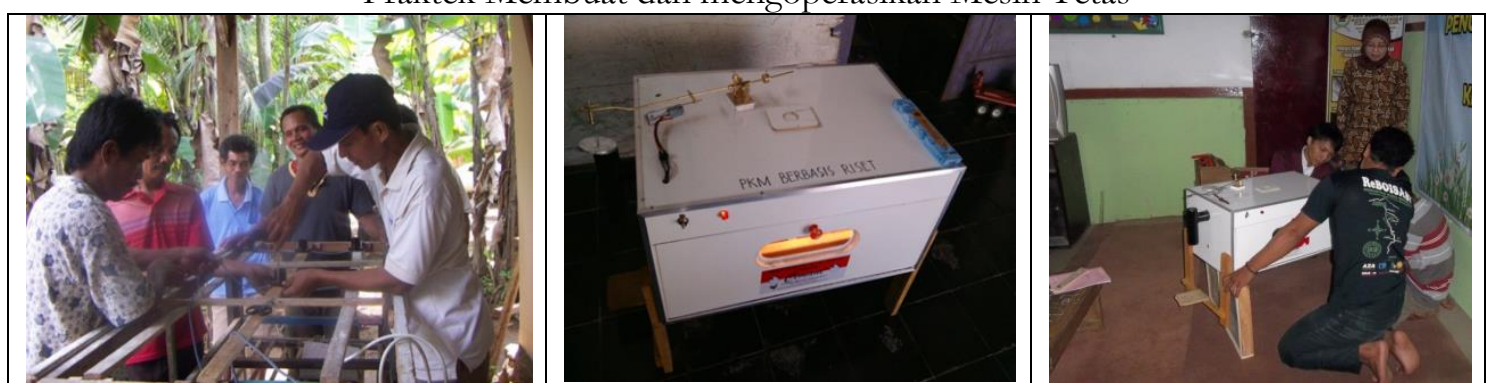

Praktek kedua yang dilakukan adalah membuat mesin tetas dari bahan kayu yang sudah disediakan oleh para anggota kelompok mitra, kemudian dilanjutkan praktek cara mengoperasikan mesin tetas seperti terlihat pada Gambar 2.
Sebelum praktek penetasan dilakukan praktek cara melakukan inseminasi buatan pada itik, sehingga telur yang akan ditetaskan adalah merupakan telur hasil dari itik yang di IB. Adapun jumlah itik yang di IB dan jumlah pejantan yang disadap tertera pada Tabel 2.

Tabel 2.

Hasil Inseminasi Buatan pada Itik

\begin{tabular}{|c|c|c|}
\hline Praktek IB yang ke & Jumlah Itik Betina yang Di-IB & Jumlah pejantan yang Disadap \\
\hline 1 & 10 & 2 \\
\hline 2 & 18 & 4 \\
\hline 3 & 22 & 4 \\
\hline
\end{tabular}

Tabel 3.

Jumlah produksi telur itik hasil IB dan Fertilitasnya

\begin{tabular}{|c|c|c|}
\hline \multirow{2}{*}{ Hari ke } & \multicolumn{2}{|c|}{ Jumlah Produksi telur } \\
\cline { 2 - 3 } & butir & Persen \\
\hline 1 & 9 & 90 \\
\hline 2 & 26 & 92,8 \\
\hline 3 & 34 & 70,8 \\
\hline Fertilitas & 45 & 65,2 \\
\hline
\end{tabular}

Praktek ketiga adalah cara memfermentasi daun sukun, yaitu dimulai dengan membuat irisan tipis2 daun sukun segar, kemudian dikeringkan dengan sinar matahari sampai dengan kadar air kurang lebih 25-30\%, setelah itu di lakukan fermentasi. Caranya adalah sebagai berikut: 1). disiapkan bahan - bahan untuk fermentasi yaitu ampas teh, EM 4, molases, air dan plastisk. 2). Disiapkan ampas teh sebanyak 700 g dalam plastik. 2). Ditambahkan $1 \mathrm{ml}$ EM 4 dan $1 \mathrm{ml}$ molases yang diencerkan secara dengan air sebanyak 50 ml. 3). Larutan EM4 disemprotkan ke daun sukun dan aduk secara merata. 4). Setelah itu diinkubasi selama $7 \times 24$ jam dengan kondisi anaerob pada suhu ruang. 
Gambar 3.

Persiapan Fermentasi Daun Sukun
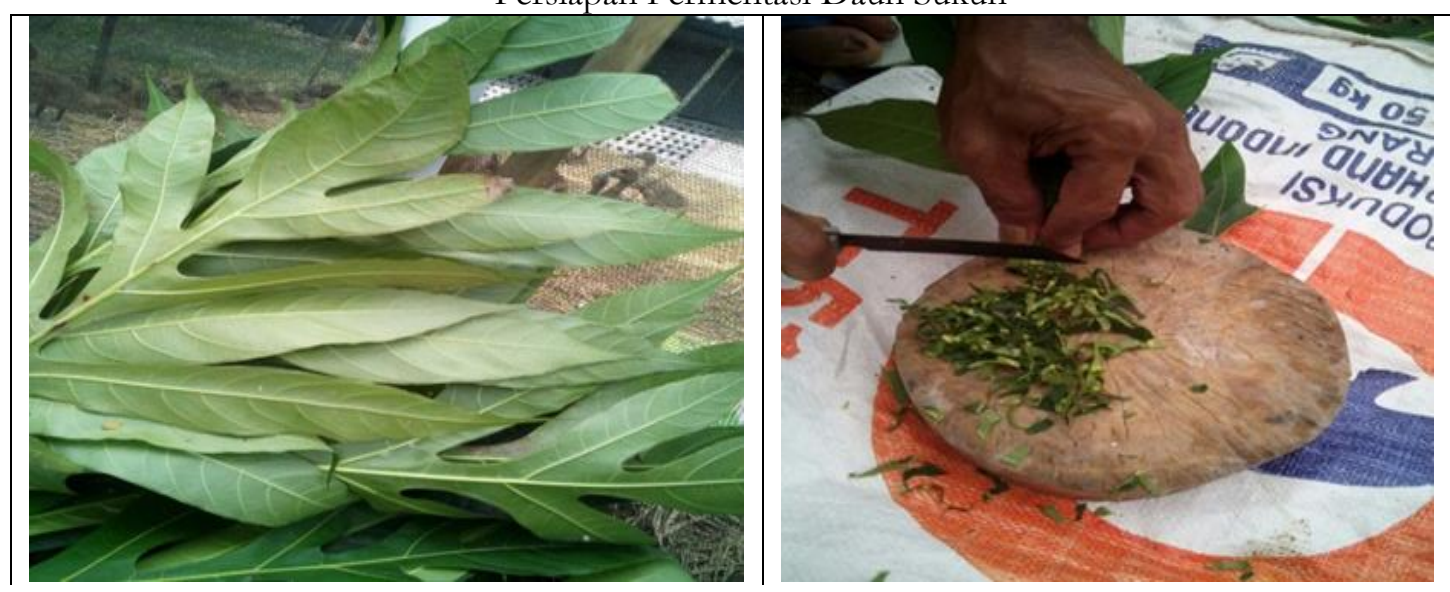

Setelah 7 hari daun sukun di fermentasi, kemudian di buka untuk mengetahui fermentasi sukses atau tidak, bahan di cium jika baunya segar menandakan bahwa daun sukun fermentasi layak dicampurkan ke dalam bahan pakan, namun sebelumnya diangin-anginkan terlebih dahulu.

Gambar 4.

Saat Pencampuran Pakan

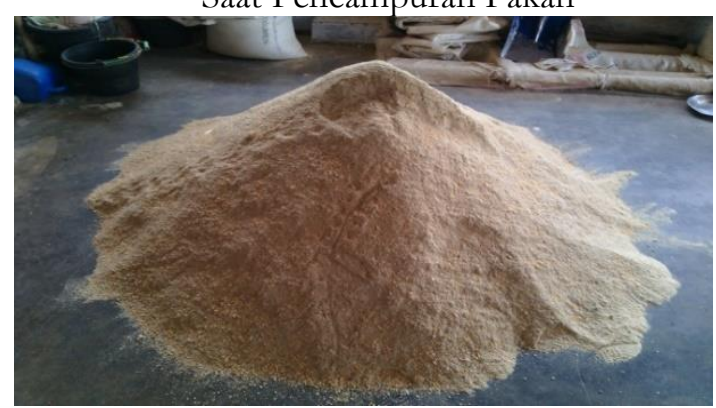

Gambar 5b.

Itik Betina Siap Bertelur

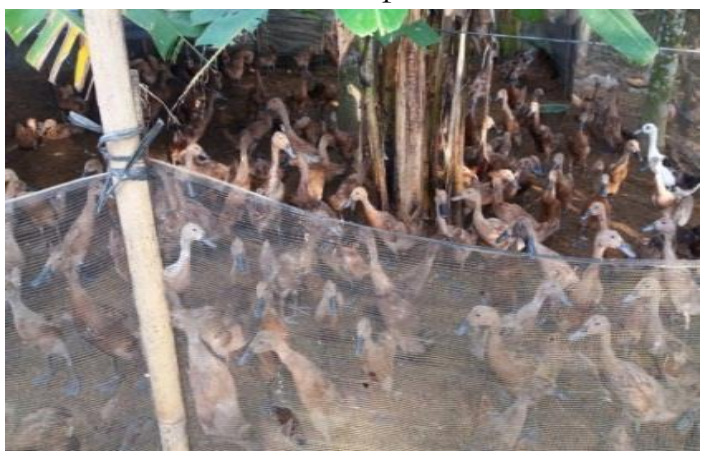

Gambar 5c.

Telur Itik

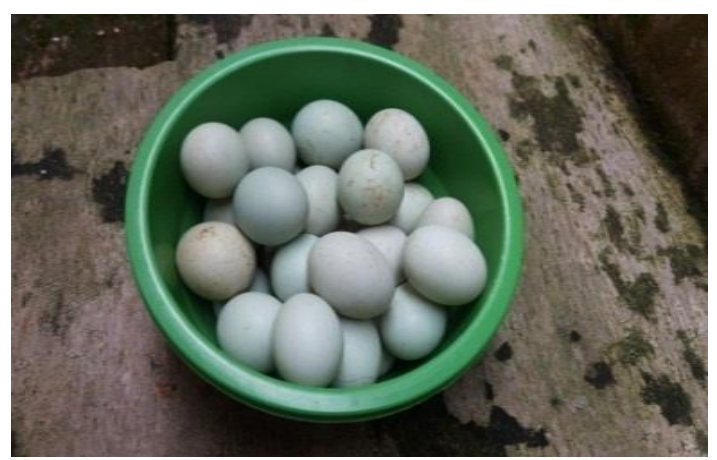

Gambar 5a.

Itik Jantan Umur 3 Minggu

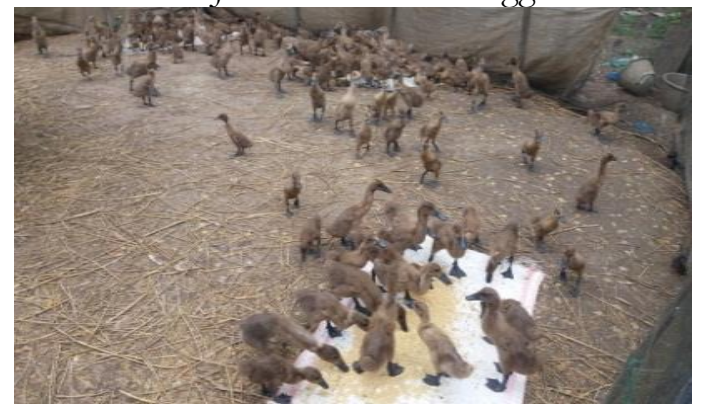

Performan itik selama demo diukur yaitu dengan cara itik ditimbang yang dilakukan satu minggu sekali yaitu saat hari minggu. Data selengkapnya dapat dilihat pada Tabel 4 
Tabel 4.

Bobot Badan Itik Jantan

\begin{tabular}{|c|c|c|}
\hline $\begin{array}{c}\text { Minggu } \\
\text { ke }\end{array}$ & $\begin{array}{c}\text { Konsumsi } \\
\text { pakan (ekor/g) }\end{array}$ & $\begin{array}{c}\text { Rataan Bobot } \\
\text { Badan }(\mathrm{g})\end{array}$ \\
\hline DOD & 20 & $42,45 \pm 2.35$ \\
\hline 1 & 25 & $110,25 \pm 2,91$ \\
\hline 2 & 35 & $242,40 \pm 3,49$ \\
\hline 3 & 45 & $502,65 \pm 10,80$ \\
\hline 4 & 60 & $768,48, \pm 14,20$ \\
\hline 5 & 70 & $998,90 \pm 17,50$ \\
\hline 6 & 90 & $1320 \pm 17,40$ \\
\hline 7 & 110 & $1540,50 \pm 22,60$ \\
\hline
\end{tabular}

Selain melakukan penimbangan bobot badan itik, juga dilakukan pengukuran produksi telur itik betina yang pakannya diberi daun sukun fermentasi mulai itik tersebut siap bertelur. Jumlah itik siap bertelura ada 62 ekor, adapun produksinya dapat dilihat pada Tabel 5 .

Tabel 5.

Produksi dan Bobot Telur Itik

\begin{tabular}{|c|c|c|}
\hline $\begin{array}{c}\text { Produksi } \\
\text { minggu ke }\end{array}$ & $\begin{array}{c}\text { Produksi } \\
\text { Telur }(\%)\end{array}$ & $\begin{array}{c}\text { Bobot Telur } \\
(\mathrm{g})\end{array}$ \\
\hline 1 & 2 & 48 \\
\hline 2 & 5 & 50 \\
\hline 3 & 12 & 53 \\
\hline 4 & 15 & 55 \\
\hline
\end{tabular}

Kadar nutrien dari telur yang dihasilkan kemudian diukur dengan cara di analisis proksimat di Lab. PBMT Fak. Peternakan UNSOED. Hasilnya dapat dilihat pada Tabel 6 .

Tabel 6.

Kandungan Gizi Telur Itik Yang Pakannya Disuplementasi Dengan Tepung Daun Sukun Yang Difermentasi

\begin{tabular}{|c|l|c|c|}
\hline No & Zat & \multicolumn{2}{|c|}{$\%$} \\
\cline { 3 - 4 } & Gizi & $\begin{array}{c}\text { Sebelum } \\
\text { pakan diberi } \\
\text { tepung daun } \\
\text { sukun }\end{array}$ & $\begin{array}{c}\text { Setelah pakan } \\
\text { diberi tepung } \\
\text { daun sukun } \\
\text { fermentasi }\end{array}$ \\
\hline 1 & Air & 70,4 & $71,88 \%$ \\
\hline 2 & Protein & 13,1 & 12,83 \\
\hline 3 & Lemak & 13,2 & 10,86 \\
\hline 4 & $\begin{array}{l}\text { Serat } \\
\text { Kasar }\end{array}$ & - & - \\
\hline 5 & Abu & 2,2 & 4,6 \\
\hline
\end{tabular}

\section{Pendampingan dan Pengkaderan untuk keberlanjutan program}

Hasil program pengabdian pada masyarakat berbasis riset tahun pertama merupakan titik awal dari program yang akan dilakukan selama 3 tahun, oleh karena itu perlu dilakukan pendampingan sekaligus pengkaderan dengan tujuan agar program ini dapat terus berlanjut dan petani sudah dapat untuk mengerjakannya. Selain itu agar memotivasi kelompok agar mereka untuk mau berinovasi memanfaatkan sumber daya alam untuk pakan itik yang berkualitas dan murah harganya.

\section{KESIMPULAN}

1. Pemberian tepung daun sukun terfermentasi dalam pakan dapat memperbaiki performan itik ( sehat, tidak ada yang mati) sehingga saat di IB dapat menghasilkan fertilisasi telur sebanyak $65,2 \%$ dan saat ditetaskan daya tetasnya mencapai $80 \%$.

2. Pemberian tepung daun sukun terfermentasi dalam pakan dapat memperbaiki kualitas telur itik terutama kandungan nutriennya.

\section{DAFTAR PUSTAKA}

BPS Provinsi Jawa Tengah. (2016). Populasi Ternak Itik. Semarang: Badan Pusat Statistik Jawa Tengah.

BPS Kab. Banyumas. (2014). Kecamatan Patikraja Dalam Angka 2014. Retrieved November 12, 2018 from bttps:// banyumaskab.bps.go.id/publikasi. $\underline{b t m l}$

Direktorat Jenderal Peternakan dan Kesehatan Hewan. (2015). Statistik Peternakan dan Kesehatan Hewan 2015. Jakarta: Direktorat Jenderal Peternakan dan Kesehatan Hewan. Kementrian Pertanian Republik Indonesia..

Exler, J., Phillips, K. M., Patterson, K. Y., \& Holden, J. M. (2013). Cholesterol and vitamin D content of eggs in the US retail market. Journal of food composition and analysis, 29(2), 110-116. 
Hakim, E. H. (2007). Keanekaragaman Hayati Sebagai Sumber Keanekaragaman Molekul Yang Unik dan Potensial untuk Bioindustri. Laporan tahunan. Bandung: Institut Teknologi Bandung.

Huda, N., Putra, A. A., \& Ahmad, R. (2011). Potential application of duck meat for development of processed meat products. Current Research in Poultry Science, 1(1), 1-11.

Ismoyowati, I., Iriyanti, N., \& Santosa, A. (2012). The differences of physical, chemical and fatty acid profile of meat quality of male muscovy (Cairina moschata) and local duck (Anas plathyrinchos). Journal of the Indonesian Tropical Animal Agriculture, 37(4), 250256.

Gray, J. I., Gomaa, E. A., \& Buckley, D. J. (1996). Oxidative quality and shelf life of meats. Meat science, 43, 111-123.

Mulyati, S. (2009). Isolasi dan Karakterisasi Siklokomunol Dari Daun Sukun (Artocarpus Altilis). Skripsi. Sukabumi: Universitas Muhammadiyah Sukabumi.

Mustafa, A.M. (1998). Budidaya Sukun. Jakarta:Universitas Terbuka.

Poedjiadi A, Supriyanti, T., Soemodimedjo, P. (2005). Dasar-dasar Biokimia. Jakarta: Universitas Indonesia Press.

Tugiyanti, E. (2015). Pengaruh Kadar Protein Dan Energi Metabolis Pakan Yang Disuplementasi Vitamin $E$ dan $C$ Terhadap Kinerja Produksi, Kualitas, Warna dan Aroma Daging Itik Manila. Disertasi. Yogyakarta: Fakultas Peternakan UGM.

Tugiyanti, E., Setianto, N. A., Harisulistyawan, I., Susanti, E., \& Mastuti, S. (2016). Effect of Breadfruit Leaf Powder (Artocarpus altilis) on Performance, Fat and Meat Cholesterol Level and Body Immune of Male Native Tegal Duck. International Journal of Poultry Science, 15(6), 227-234.
Umar, A., Jenie, L, Kardono., Mozef., T., Jiaan, C., Xiaoxiang, Z., Yuanjiang, P. (2007). Ekstrak total flavonoid dan fitosterol daun sukun (Artocarpus altilis) sebagai obat kardiovaskuler dan teknik produksinya. Paten Indonesia terdaftar No.P00200700707 